\title{
Women and Men Linguistic Features in the First Presidential Debate Hillary Clinton and Donald Trump in 2016
}

\author{
Ashari Jamangantar Siregar ${ }^{1}$, I Made Suastra ${ }^{2}$ \\ ${ }^{[1]}$ English Department, Faculty of Arts, Udayana University \\ Denpasar, Indonesia \\ Email: asharijamangantarsiregar17@gmail.com \\ ${ }^{[2]}$ English Department, Faculty of Arts, Udayana University \\ Denpasar, Indonesia \\ Email:madesuastra@yahoo.com
}

\begin{abstract}
This undergraduate thesis entitled Women and Men Linguistic Features in The First Presidential Debate Hillary Clinton and Donald Trump in 2016 was aimed at analyzing the women linguistic features represented by Clinton utterances based on Lakoff (1975) theory and men linguistic features represented by Trump based on Coates (2003) theory and at investigating the implication of the dominant women and men linguistic features. The data were taken from the debate video of NBC YouTube channel and its transcript is taken from the Washington Post website. The method used in collecting data was the documentary method applying the note-taking technique. The qualitative and quantitative method was applied in analyzing the data. In presenting the analysis, formal and informal methods were used. The analysis results showed that there seven features of ten women linguistic features discovered in this study; they were lexical hedges, rising intonation on declarative, empty adjectives, intensive adverbs, hypercorrect grammar, super polite forms, and emphatic stress whereas features such as tag questions, avoidance of strong swear words and precise color terms were not found in this study. In this study, there are only three of four men linguistic features such as stereotypically masculine topics, great attention to details, elaborate use of taboo words whereas men only features were not used in Trump utterances. And the dominant features found in Clinton utterances were emphatic stress while in Trump, the dominant feature was great attention to details.
\end{abstract}

Keywords: Debate, Women's Linguistic Features, Men's Linguistic Feature

\section{INTRODUCTION}

Language cannot be separated from the daily life of humankind since it is the medium for transferring and exchanging the thoughts of each individual to others. The use of language can vary depending on gender, age, race, the social class that influences the way people talk. It is related to the domain study of sociolinguistics which covers the language used in society. The reason why this study becomes interesting to be raised is to understand the language used by women and men. To communicate properly in society, it is necessary to avoid the misunderstanding that could happen to result from the language gender differences between the speaker and the hearer. Therefore, to achieve good communication, it is needed to comprehend women's and men's linguistic features.

Lakoff (1975) stated that women uttered more words in a day compared to men, and she defined ten linguistic features that belong to women and their functions in the speech that indicate that women have wide vocabulary than men. Coates (2003) stated the linguistic features of men are only four which are stereotypically masculine topics. Men usually pay great attention to details and elaborate on the use of taboo words. And Coates (2004:86) stated that people believe that women talk more than men, that women do 'gossip', and men swear more than women, ergo women tend to be more polite.

The phenomenon in the first presidential debate in 2016 showed the contrary. Struyk (2016) has done statistic calculations published in ABC News Website which showed that Trump spoke about 8,455 words whereas Clinton just 6,119 words. And the exit polls or the surveys done by CNN categorized the percentage of the voters sorted by their gender showed that the male voters were voting more for Trump by $52 \%$ and Clinton by only $41 \%$. The female voters were voting more for Clinton by $54 \%$ and for Trump only by $41 \%$. However, when if seen from race and gender polling, Trump won by the voters of white men by $62 \%$ and white women by $52 \%$. And Clinton won from other race voters such as black men by $82 \%$, black women by $94 \%$, Latino men by $63 \%$, Latino women by $69 \%$ and others by $61 \%$.

The reason for choosing this data was that it has excellently represented both women's and men's languages. Furthermore, as the presidential debate is surely reflecting the reality of social conditions in a certain country, in this case, America, the debate 
motion source comes from all the matters dealt with in real life in many social aspects. It makes the presidential debate become the authentic data because it happened in the natural situation without any manipulation. The debate candidates certainly delivered their thoughts and arguments using language. It was also interesting because both Hillary and Trump were in the same status and roles as the candidates for US president; supposedly, they were using the same linguistic features but the truth was they were not.

The explanation above shows that the sexual differences are still influencing the social roles so that both biological differences have their linguistic features. If some differences happen, they result from sexual identity and not from the role in society. It made the focus in this study on women's and men's linguistic features; the women's language was taken from Hillary Clinton utterances and the men language was taken from Donald J. Trump.

\section{Problems of the Study}

Based on the background stated above, the research problems can be stated as follows:

a. What are women's and men's linguistic features in The First Presidential Debate in 2016?

b. What are the implications of the dominant women and men's linguistic features in The First Presidential Debate 2016?

\section{Aims of the Study}

Based on the problems mentioned above, the aims of this study can be stated as follows:

a. To analyze the women's and men's linguistic features in The First Presidential Debate 2016.

b. To find the implication of the dominant women's and men's linguistic features in The First Presidential Debate 2016.

\section{RESEARCH METHOD}

The research method in this study consists of (1) data source, (2) method and technique of collecting data, (3) method and technique of analyzing the data, and (4) method and technique of presenting data that are explained furthermore in the following sections.

\section{Data source}

There were two data in this study; they were primary and secondary data. The primary data of this study were spoken data taken from the presidential debate video entitled "The First Presidential Debate Hillary Clinton and Donald Trump 2016 Full Debate" and the written data were taken from the debate transcript taken from The Washington Post website. This debate was held at Hofstra University, New York on Monday, September 26, 2016, aired on NBC TV and YouTube channel. The secondary data were taken from $\mathrm{ABC}$ News and $\mathrm{CNN}$ website. The data were about the total words uttered by two candidates, their speaking time in the debate, and polling of the candidate's voters categorized by their race and their gender. These data were chosen to be analyzed because they were authentic data source as taken from the real event. It is interesting to analyze how they responded to each other since they, Hillary and Trump, both had the same status and roles as the candidates for the US president and whether they used the same linguistic features or not in responding to each other in the debate.

\section{Method and Technique of Collecting Data}

The method used in collecting data is the documentary method. It means that the data were collected by downloading the debate video, watching and listening to it, and reading the transcript, and taking down more information related to the conflicts. The process of collecting data are as follows: firstly, downloading the transcript and the video in NBC News YouTube channel; Secondly, watching and listening intensively to the utterances of Hillary Clinton and Donald Trump provided with the transcript, while looking into some references of women and men linguistic features. Thirdly, notetaking the utterances indicating the linguistic features, marking the dialogues, and the sentences in the transcript when the utterances were being spoken and ordering them in a list or a table.

\section{Method and Technique of Analysing Data}

The qualitative and quantitative method was applied in analyzing the data. This method was used since this study analyzed the form of texts and numerical data. There were some steps in analyzing the data, such as classifying women's linguistic features based on the theory proposed by Lakoff (1975), men linguistic features based on the theory proposed by Coates (2003), and then examined the implication of the dominant features found in this study.

\section{Method and Technique of Presenting Data}

In presenting the analysis, formal and informal methods were used. The formal method was used because the findings are presented in the form of a table. The informal method was used to describe and explain the table and the findings in the form of sentences.

\section{RESULTS AND DISCUSSION}

\section{The Analysis of Women Linguistic Features}

a. Lexical Hedges or Fillers

Data 1. Dialogue 5; Sentence 2

CLINTON: Well, I think that trade is an important issue. 
It can be seen from the example above that there were two lexical features found in this utterance. The word well in her utterances indicated part of lexical fillers and $\boldsymbol{I}$ think it is categorized as part of lexical hedges. It showed that she lacks confidence and uncertain about her statement. She was thinking first before she expressed her feeling.

\section{b. Rising Intonation on Declarative Context \\ Data 1. Dialogue 65; Sentence 17 \\ ...And you know what else I \\ prepared for?...}

Clinton gave stress and raised the intonation of her voice at the end of her statement. The examples above indicated rising intonation for she tended to raise her intonation to get attention from his opponent and she was hesitant about her statement.

\section{c. Empty Adjectives}

Data 1. Dialogue 14; Sentence 2

...I think my husband did a pretty good job in the 1990 s...

She said that her husband did a pretty good job. She employed the word pretty in her utterance as approbation or admiration for her husband done in his work. The word pretty was suitable to be classified as an empty adjective as it was used for the speaker's approbation or admiration for something. In this case, the word pretty is classified as an adjective for women only.

\section{d. Intensive Adverbs}

Data 1. Dialogue 13; Sentence 5

CLINTON: Well, actually, I have thought about this quite a bit.

The word quite here role as an adverb that modifies the verb thought in Clinton's utterance. Therefore, the word quite is categorized as an intensifier since Clinton used it to emphasize and strengthen her statement.

\section{e. Hypercorrect Grammar}

Data 1. Dialogue 24; Sentence 1

CLINTON: In fact, I have written a book

The sentence I have written is suitable to present perfect tense formula which is $\mathrm{S}+\mathrm{Has} / \mathrm{Have}$ + Verb 3. Therefore, it is classified as a hypercorrect grammar for her utterance in the right sentence structure.

\section{f. Superpolite Forms}

Data 1. Dialogue 28; Sentence 3

...please go and take a look...
She employed the word please in her utterance that showed politeness rule to give options to the addressee. Clinton in these circumstances knew very well that the addressee had the power to enforce a decision. Therefore, the word please is classified as a super polite form since Clinton used it to make a request and suggestion to the audience in her utterance.

\section{g. Emphatic Stress}

Data 1. Dialogue 63; Sentence 4

... New York has done an excellent job.

In complimenting, she used the word excellent which means extremely good to show that she was expressing her approval to New York people for their good work to fight crime. Therefore, it is classified as emphatic stress for Clinton used it to emphasize her judgment on the work of New York people.

\section{The Analysis of Men Linguistic Features}

a. Stereotypically Masculine Topics

Data 2. Dialogue 56; Sentence 22

...We have gangs roaming the street.

The utterance above is classified as stereotypically masculine topics since Trump raised the masculine topics. The possession of guns and dealing with gangs are mostly done by men as it is useful to show their masculinity.

\section{b. Great Attention to Details}

Data 2. Dialogue 39; Sentence 5

TRUMP: Who gave it that name? The first I've -who gave it that name?

Trump interrupted Clinton's when she said the terms of Trump loophole and at the same time demanding the detail of information of the terms by saying who gave it that name. Therefore, it is classified as great attention to detail since he insisted to get detailed information about the terms that Clinton gave to his tax proposals.

\section{c. Elaborate Use of Taboo Words}

Data 2. Dialogue 76; Sentence 26

...we have to knock the hell out of ISIS, ...

Trump used the phrase knock the hell out instead of using the phrase knockdown or the words destroy on how ISIS should be treated. The phrase knocks the hell out is included as a swear or taboo word category. Therefore, it is classified as a feature of elaborate use of taboo words for Trump used it to express his furious feeling about ISIS. 


\section{The Analysis of the Implication of the Dominant Women and Men Linguistic Features}

Table 1: Lakoff's Women Linguistic Features Used by Hillary Clinton

\begin{tabular}{|c|c|c|c|}
\hline No. & Linguistic Features & Quantity & $(\%)$ \\
\hline 1 & Emphatic Stress & 168 & $31.3 \%$ \\
\hline 2 & $\begin{array}{l}\text { Hypercorrect } \\
\text { Grammar }\end{array}$ & 162 & $30.2 \%$ \\
\hline 3 & Intensive Adverbs & 94 & $17.5 \%$ \\
\hline 4 & $\begin{array}{l}\text { Lexical Hedges or } \\
\text { Fillers }\end{array}$ & 94 & $17.5 \%$ \\
\hline 5 & Superpolite Forms & 10 & $1.9 \%$ \\
\hline 6 & Empty Adjectives & 6 & $1.1 \%$ \\
\hline 7 & $\begin{array}{l}\text { Rising } \\
\text { Intonationon } \\
\text { Declarative }\end{array}$ & 2 & $0.4 \%$ \\
\hline 8 & Tag Questions & - & - \\
\hline 9 & $\begin{array}{lr}\text { Avoidance } & \text { of } \\
\text { Strong } & \text { Swear } \\
\text { Words } & \end{array}$ & - & - \\
\hline 10 & $\begin{array}{l}\text { Precise } \\
\text { Terms }\end{array}$ & - & - \\
\hline & Total & 536 & $100 \%$ \\
\hline
\end{tabular}

Table 2: Coates' Men Linguistic Features Used by Donald Trump

\begin{tabular}{lllll}
\hline No & Linguistic Features & Quantity & $\%$ \\
\hline 1 & Great Attention to & 9 & $69,2 \%$ \\
& $\begin{array}{l}\text { Details } \\
2\end{array}$ & $\begin{array}{l}\text { Stereotypically } \\
\text { Masculine Topics }\end{array}$ & 2 & $15,4 \%$ \\
3 & $\begin{array}{l}\text { Elaborate Use of } \\
\text { Taboo Words }\end{array}$ & & $15,4 \%$ \\
4 & Men Only & - & - \\
\hline & Total & 13 & $100 \%$ \\
\hline
\end{tabular}

The dominant features seen from their percentages showed that she used emphatic stress more often. The emphatic stress percentages in Clinton's utterances were $31,3 \%$ from 168 out of 537 total features and it was more frequent to use than the other features. One thing that should be done by the candidates to win the election is to get voted as many as possible. Since the candidates aimed to join the debate event for convincing their ideas to the voters and influencing the voters to decide to vote one of them to be the 45th US President.

As an implication result, the emphatic stress features were used more often than the other features for its functions to signal an emphasis on a certain part of expression or utterance. Women tend to use words to strengthen or to emphasize a certain part of their utterances to help them convey the specific meaning of their utterances. Women usually strengthen their utterances to describe their judgment about something. In the debate, Hillary used it to strengthen her judgment about her feelings and ideas as well as expressed her judgments about her opponent's arguments. It proved that she was trying to be confident to convey her arguments or thoughts to master the stage and made the audiences trust her.

The second table shows the dominant men features used by Donald Trump. It could be seen that Trump used three out of four men features sorted by the highest percentage of men linguistic features such as great attention to details by $69,2 \%$, stereotypically men topics, and elaborate use of taboo words were in the same percentage by $15,4 \%$. Meanwhile, men's only features were not found in his utterances.

Great attention to detail becomes the dominant features used by Trump, there were 9 from 13 total features. Men usually have a propensity to pay attention to details in their masculine conversation. As usually seen in a presidential debate where there must be some arguments from each contestant, both candidates were delivering each of their opinions and arguments in this debate. Clinton appeared to be accusing Trump several times in the debate. As a result, rather than denying Clinton's accusation of him, Trump preferred to seek the truth by demanding and asking more details to her directly about where she got such information that she used to accuse him. Therefore, the audience could consider whether the accusation of Clinton about him was true or false. Men's only features did not appear to be used in Trump's utterances. It was not used because these features required men with men conversation only and the debate circumstances happened to be a mixed-gender conversation.

\section{CONCLUSION}

There were seven features from ten women linguistic features discovered in this study; they were lexical hedges, rising intonation on declarative, empty adjectives, intensive adverbs, hypercorrect grammar, super polite forms, and emphatic stress whereas features such as tag questions, avoidance of strong swear words and precise color terms were not found in this study.

The emphatic stress was the dominant feature with the percentage of $31,3 \%$ from 168 out of 537 total features and it was more frequent to be used than the other features. She used for convincing their ideas to the voters and influencing the voters to decide to vote one of them to be the 45th US President. As a result, the emphatic stress features were used more often than the other features for its function to signal an emphasis on a certain part of expression or utterance. Hillary used it to strengthen her judgment about her feelings and ideas as well as expressed her judgments on her opponent's arguments. It proved that she was trying to be confident to convey her arguments or thoughts to 
master the stage and made the audiences trust them using emphatic stress.

And there were three from four men linguistic features used by Donald Trump discovered in this study; they are stereotypically masculine topics, great attention to details, elaborate use of taboo words, and men only features did not appear to be used in Trump's utterances. The features of great attention to details become dominant to be used in his utterances by $69,2 \%$ from 9 out of 13 total features. He used it to seek the truth by demanding and asking more details to her directly about where she got such information that she used to accuse him.

\section{REFERENCES}

Blake, Aaron. (2016). The First Trump-Clinton Presidential Debate Transcript [Internet]. The Washington Post, Washington. Available from: https://www.washingtonpost.com/news/thefix/wp/2016/09/26/the-first-trump-clintonpresidential-debate-transcript annotated/?noredirect $=$ on\&utm term $=$. . $f 47$

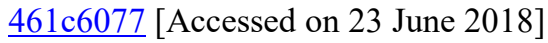

Coates, Jennifer. (2003). Men Talk: Stories in the Making of Masculinities. Blackwell, Malden.

Coates, Jennifer. (2004). Women, Men, and Language $3^{R D}$ Edition. Routledge, New York.

Creswell, John W. (2013). Qualitative Inquiry and Research Design: Choosing Among Five Approaches. Sage, Lincoln.

Dharma Sanjaya, Ida Bagus Gede. (2018). Women's Language In "The Nanny Diaries" Movie (Thesis). Udayana University, Denpasar.

Exit Polls 2016. [Internet]. Available From: https://edition.cnn.com/election/2016/results lexit-polls [Accessed on 23 December 2018]

Holmes, Janet. (2013). An Introduction to Sociolinguistics. Routledge, New York.

Kasni, Ni Wayan \& Budiarta, I Wayan (2017). Balinese Women and Men and Their Language. International Journal of Linguistics. Vol. 9, No. 5, October, 247-260.

Lakoff, Robin. (1975). Language and Woman's Place. Cambridge University Press, England.
Owen, Patricia R \&Padron, Monica. (2016). The Language of Toys: Gendered Language in Toy Advertisements. Journal of Research on Women and Gender. 6, 67-80.

Oxford Dictionaries [Internet]. Available from: https://en.oxforddictionaries.com/definition/ debate [Accessed on 25 June 2018]

Presidential Debate. 1. The First Presidential Debate Hillary Clinton And Donald Trump Full Debate. (2016). NBC, Hofstra University, New York, 26 September, [Video: Internet]. Available from: https://www.youtube.com/watch?v=855Am 6ovK7s [Accessed on 23 June 2018]

Sari Dewi, Ni Putu Erna Meryanti. (2017). The Features of Men's and Women's Language In The Movie Camp Rock 2: Final Jam (Thesis). Udayana University, Denpasar.

Struyk, Ryan. (2016). The First Presidential Debate: By the Numbers. [Internet] The ABC News, Washington DC. Available from: https://abcnews.go.com/Politics/presidential -debatenumbers/story? $\mathrm{id}=42401099$ [Accessed on 02 February 2019]

Wulandari, Putu Jayanti. (2015). The Analysis of Men's and Women's Linguistic Feature in OZ the Great and Powerful Movie Script (Thesis). Udayana University, Denpasar. 